\title{
Studia theodisca XXVIII
}

Stefan Zweig • Joseph Roth • Robert Musil Alfred Kubin • Monika Maron Wolfgang Herrndorf

Editor-in-chief: Fausto Cercignani Co-Editor: Marco Castellari

Editorial Board

Ursula Amrein (Universität Zürich)

Rüdiger Campe (Yale University)

Alberto Destro (Università degli Studi di Bologna)

Katharina Grätz (Albert-Ludwigs-Universität Freiburg)

Isabel Hernández (Universidad Complutense de Madrid)

Primus-Heinz Kucher (Universität Klagenfurt)

Sylvie Le Moël (Université Paris-Sorbonne)

Paul Michael Lützeler (Washington University in St. Louis)

Sandra Richter (Universität Stuttgart)

Ronald Speirs (University of Birmingham) 


\section{Studia theodisca}

An international journal devoted to the study of German culture and literature Published annually in the autumn

\section{ISSN 2385-2917}

\section{Vol. XXVIII}

Year 2021

Editor-in-chief: Fausto Cercignani

Co-Editor: Marco Castellari

Editorial Board:

Ursula Amrein (Universität Zürich)

Rüdiger Campe (Yale University)

Alberto Destro (Università degli Studi di Bologna)

Katharina Grätz (Albert-Ludwigs-Universität Freiburg)

Isabel Hernández (Universidad Complutense de Madrid)

Primus-Heinz Kucher (Universität Klagenfurt)

Sylvie Le Moël (Université Paris-Sorbonne)

Paul Michael Lützeler (Washington University in St. Louis)

Sandra Richter (Universität Stuttgart)

Ronald Speirs (University of Birmingham)

Founded in 1994

Published in print between 1994 and 2010 (vols. I-XVII)

On line since 2011 under http:/ / riviste.unimi.it

Online volumes are licensed under a Creative Commons Attribution-

NonCommercial-NoDerivs 3.0 Unported License.

The background image of the cover is elaborated

from the original of Georg Büchner's "Woyzeck" (F4-2v). 


\section{Studia theodisca \\ Vol. XXVIII - Year 2021}

\section{Table of Contents}

Stefan Krammer - Abenteuer Männlichkeit. Adoleszenz in Wolfgang Herrndorfs Roman «Tschick»

p. 5

[Adventure Manhood. Adolescence in Wolfgang Herrndorf's Novel «Tschick»]

Giulia Fanetti - Il demiurgo è ibrido, ovvero ermafrodita. Letture postasburgica e postcoloniale di «Die andere Seite» di Alfred Kubin

p. 25

[The demiurge is a bybrid, that is a hermaphrodite. Post-Habsburg and post-colonial interpretations of «Die andere Seite» by Alfred Kubin]

Paola Gheri - «Wir haben jetzt die Demokratie, das ist kompliziert genug». Zur Krise demokratischer Systeme und Auflösung des Politischen in "Munin oder Chaos im Kopf» von Monika Maron

p. 43

["Now we have democracy, that is complicated enough». On the crisis of democratic systems and the decline of politics in «Munin or Chaos in the Head» by Monika Maron]

Erika Capovilla - «Freilich ist Freundschaft wahre Heimat». Il carteggio di Stefan Zweig e Joseph Roth come patria spirituale

[ FFriendship is indeed true homeland》. The correspondence between Stefan

p. 63 Zweig and Joseph Roth as spiritual homeland]

Mariaelisa Dimino, Simone Rebora, Massimo Salgaro - Ein Schlachtfeld der Zuschreibung von Autorschaft. Musils propagandistische Beiträge in der Frontzeitung "Heimat» (1918)

[A battlefield for authorship attribution. Musil's propaganda contributions in the soldier's newspaper «Heimat» (1918)]

Call for Papers

p. 133 
*** 